\title{
MANIFESTASI TUHAN PADA TUBUH MANUSIA DALAM TEKS ANGGASTYA PRANA
}

Oleh :

\author{
I Nyoman Piartha
}

Dosen pada Fakultas Brahma Widya IHDN Denpasar

\begin{abstract}
The human body in the concept of Hinduism consists of three layers called Tri Sarira, namely: Sthula Sarira (body), Suksma Sarira (subtle body) and Anthakarana Sarira (causative body). Stula Sarira or coarse body is the outermost layer of the human body which is formed from the Panca Maha Buta, which consists of: Pertiwi (solid element), Apah (liquid element), Bayu (air element), Teja (heat / light element), and Akasa (ether). Suksma Sarira or subtle body which is a layer of the body that cannot be seen or touched, but is present in mankind for example the mind. Anthakarana Sarira is a fine layer that is the cause of human life called Atman. Birth is closely related to the procurement of offspring, serves to pay birth debt. Debt in Sanskrit is called Rna, which developed into Tri Rna, including: debt to the Gods (Dewa Rna), debt to parents or ancestors (Pitra Rna), and debt to the Rsi (Rsi Rna). In "Lontar Anggastya prana" it is told that the life of the baby while in the womb the mother is guarded and protected by Hyang Siwa / Siwatma.

The process of creation (uttpti) begins with interest or liking at the age of adolescence until the relationship occurs / intercourse until fertilization occurs between spermatozoid (kama petak) with ovum (kama bhang) becomes Sang Hyang Antigajati in the form of the seed of life. When a child is looking for birth, he is called Sang Hyang Siwatma. When humans are born into the world, he is accompanied by four brothers called Chess Sanak in the form of Yeh Nyom (amniotic fluid), placenta, shampoo, and blood. The Catur Sanak accompanies humans from birth as Sang Anggapati, Sang Prajapati, Sang Bhanaspati, and Sang Bhanaspatiraja, until humans die and change their designation according to human development, and continue with the depiction of God in the human body in the form of sacred characters.
\end{abstract}

Keywords: God, Man, Anggastya Prana

\section{PENDAHULUAN}

Manusia dalam konsep agama Hindu memiliki konsep ketuhanan yang melekat pada diri manusia, dari masih dalam kandungan sampai setelah kematian. Kelahiran seorang manusia berarti awal dari kehidupan manusia itu sendiri, namun merupakan kelanjutan dari konsep ketuhanan yang melekat padanya. Begitu pula halnya dengan kematian berarti akhir dari kehidupan manusia itu, namun peningkatan dari konsep ketuhanannya. Di dalam konsep agama Hindu tubuh manusia terdiri dari tiga lapisan yang disebut dengan Tri Sarira, yaitu :Sthula Sarira (badan jasar), Suksma Sarira (badan halus) dan Anthakarana Sarira (badan penyebab).

Stula Sarira atau badan kasar adalah lapisan terluar dari tubuh manusia yang terbentuk dari Panca Maha Buta, yang terdiri dari : Pertiwi (unsur padat), Apah (unsur cair), Bayu (unsur udara), Teja (unsur panas/cahaya), dan Akasa (eter). Suksma Sarira atau badan halus yang 
merupakan lapisan tubuh yang tidak dapat dilihat maupun disentuh, namun ada di dalam diri manusia misalnya pikiran. Anthakarana Sarira adalah lapisan halus yang menjadi penyebab kehidupan manusia yang disebut dengan Atman. Atman adalah zat halus yang merupakan percikan terkecil dari Brahman (Tuhan). Di dalam teks hindu juga disebutkan bahwa "Brahman Atman Aikyam" bahwa antara Brahman dengan Atman sesungguhnya adalah tunggal. Atman yang menghidupi manusia disebut dengan Jiwatman, Atman yang menghidupi binatang disebut Janggama, dan Atman yang menghidupi binatang disebut Stawana.

Kelahiran seorang anak dalam suatu keluarga masyarakat Hindu, dipandang sebagai suatu peristiwa sejarah yang amat penting dan oleh sebab itu diperinggati dengan upacara keagamaan. Lahirnya seorang anak merupakan buah dari suatu perkawinan, yang merupakan ikatan lahir bathin antara seorang pria dengan seorang wanita sebagai suami istri bertujuan membentuk keluarga/ rumah tangga bahagia dan kekal berdasarkan Ketuhanan Yang Maha Esa (Arwati, 2005: 3). Kelahiran erat hubungannya dengan pengadaan keturunan, berfungsi untuk pembayaran hutang kelahiran. Hutang dalam bahasa Sanskerta disebut dengan Rna, yang berkembang menjadi Tri Rna, meliputi : hutang kepada para Dewa (Dewa Rna), hutang kepada orang tua atau leluhur (Pitra Rna), dan hutang kepada para Rsi (Rsi Rna).

Di dalam "Lontas Anggastya Prana" diceritakan bahwa kehidupan bayi selama berada dalam kandungan si Ibu dijaga dan dilindungi oleh Hyang Siwa/ manifestasi Tuhan yang berfungsi sebagai Pamralina. Diceritakan Dewa Siwa memberitahukan kepada Si Jabang Bayi bahwa, jika ingin lahir ke dunia harus meminta bantuan kepada Sang Catur Sanak. Dikisahkan bahwa Sang Catur Sanak bersedia membantu dan mengikuti Si Jabang Bayi selama hidupnya.

Secara biologis dapat diketahui bahwa kehidupan bayi dalam kandungan itu setiap saat mengalami perubahan, sesuai dengan pase perkembangannya. Kehidupan Si bayi didalam kandungan dipelihara dan dilindungi oleh Nyama Bajang, dan menjelang kelahiran Nyama Bajang berubah nama menjadi sang Catur Sanak atau Nyama Pat.

Anandakusuma(1985:13)menguraikan bahwa pada saat bayi lahir diikuti oleh Sang Tanu atau Sang Catur Sanak (saudara empat), meliputi : yeh nyom, lamas, darah dan ari-ari. Yeh nyom merupakan pelindugn bayi waktu di dalam kandungan dari sentuhan luar, lamas merupakan lemak halus yang membungkus tubuh bayi, darah yang bertugas mengedarkan makanan, dan ari-ari merupakan tempatmelekatnya tali pusar yang berfungsi menyerap makanan dan lain-lain.

Catur Sanak dalam proses perkembangannya, berganti-ganti nama sejak dari dalam kandungan sampai meninggal dan mempunyai sebutan yang berbeda-beda. Pada waktu masih di dalam kandungan mereka bernama : Karen, Bra, Angdian, dan Lembana. Setelah berusia 20 hari di dalam kandungan bernama : Anta, Preta, Kala, dan Dengen. Pada waktu bayi itu lahir bernama : Antamenjadi dan 
bernama ari-ari, Pretamenjadi dan bernama lamas, Kalamenjadi dan bernama darah, dan Dengen menjadi dan bernama yeh nyom (air ketuban). Ketika pusar bayi itu sudah putus, maka ia berganti nama : I Mekair, I Selabir, I Mokair, dan I Selair. Apabila anak itu sudah dapat menyebut "babu", maka empat saudaranya itu bernama : Anggapati, Prajapati, Banaspati, dan Banaspatiraja, demikian seterusnya sampai akhirnya manusia itu meninggal dan mencapai Moksa dan menjadi dewa.

Manifestsi Tuhan Teks Anggastya Prana menguraikan penggambaran Tuhan dalam diri manusiadari awal terjadi pembuahan sampai dengan kematian. Perlu pula dipahami bahwa dalam konsep agama Hindu menyatakan bahwa kelahiran manusia dipengaruhi ole konsep Tri Guna. Dalam kitab Wrhaspati tattwa menyatakan bahwa : Tri guna tattwa ngaranya satwam, rajah, tamah. Bahwa yang dimaksud Tri Guna $($ Tri $=$ tiga, Guna $=$ sifat, karakter, unsur pokok) yang menjadi dasar dari segala yang tercipta, yaitu satwam (kesenangan), rajah (bersemangat), dan tamah (lamban, malas). Dimana, sifat-sifat dari ketiga Guna itu mempengaruhi sifat dan ketuhanan dalam diri manusia.

\section{PEMBAHASAN}

\section{I Teks Anggastya Prana}

Teks Anggastya Prana murupakan salah satu teks Hindu yang menyiratkan tentang manifestasi Tuhan. Titib (2011: 341) menguraikan bahwa sebutan Tuhan dalam agama Hindu berbeda-beda sesuai dengan manifestasi Tuhan yang dipuja. Dalam ajaran Hindu tersedia tipe roh dari yang tertinggi sampai yang terendah, demi untuk pertumbuhan mereka. Pernyataan ini jelas merangkum semua kemampuan umatnya untuk membayangkan Tuhan Yang Maha Esa. Mereka yang tinggi rohaninya, Tuhan Yang Maha Esa digambarkan dalam pikirannya sebagai Imppersonal God (tanpa wujud baik dalam pikiran maupun kata-kata) sedangkan bagi yang pemahamannya sederhana, Tuhan Yang Maha Esa digambarkan senagai Personal God, berpribadi dan dibayangkan sebagai wujud-wujud yang agung, maha kasih, maha besar dan sebagainya.

Berkaitan dengan konsep pemujaan Tuhan yang Personal God, yang artinya Tuhan berpribadi dan dibayangkan dengan wujud-wujud yang agung. Ketuhanan dalam teks Anggastya Prana berarti sebutan-sebutan Tuhan dalam diri manusia yang mengiringi manusia dari sejak dalam kandunga, meninggal, dan menyatu dengan Paramatman (Tuhan). Sebutan Catur Sanak atau saudara empat dari sejak masih hidup, yaitu: Anggapati, Prajapati, Banaspati, Banaspatiraja, hingga meninggal menghadap Hyang Widhi disebut : Sang Suratma, Sang Jogormanik, Sang Maha Kala, dan Sng Dora Kala, dan sampai akhirnya menyatu dengan Hyang Widhi, disebut dengan Sang Hyang Siwa, Sang Hyang Sada Siwa, Sang Hyang Parama Siwa, dan Sang Hyang Sunia Siwa.

Kata Anggastya merujuk pada konsep orang suci agama Hindu yang sangat besar jasanya dalam penyebaran agama Hindu di seluruh dunia. Anggastya adalah orang suci yang lahir dari kota Kashia tau Banares wilayah Uttar Pradesh, India Utara. Beliau telah menyebarkan ajaran agama Hindu di India dan masuk sampai di Indonesia 
(Subagiasta, 2008: 24). Sedangkan kata Prana berarti nafas dalam Panca Bayu (Tim Penyusun, 2002: 82). Panca Bayu artinya lima tenaga, yairu Prana, Apana, Samana, Udana, dan Wyana. Wayu/Bayu yang bernama Prana berada dalam jantung hingga di dalam batasnya, yang menjadi sumber gerak semua wayu, sebagai juwanya, Gunanya ialah sebagai nafas (Tim Penyusun, 2002: 71).

Bhagawan Anggastya Prana sesungguhnya merupakan namadari salah satutokoh yang termuat dalam teks ini. Nama Anggastya yang dijadikan nama atau judul dari teks ini karena, Beliau sendirilah yang menceritakan isi teks ini kepada kedua putra-putri Beliau. TeksTutur Anggastya Praṇa dapat dikatakan sebagai salah satu Lontar Tattwa/Lontar Tutur yang di dalamnya menjelaskan bagaimanahakikat kehidupan manusia, dan membahas tentang prosesawal mula kelahiran manusia. Tubuh manusia merupakanpersonifikasi dari Bhuana Alitdan merupakan gambaran kecil dari Bhuana Agung (alam semesta). Jadi, Lontar Anggastya Prana ini menguraikan tentang tubuh manusia yang terdiri dari Angga (badan) dan Prana (jiwa), menuju harmonisasi Bhuana Agung dan Bhuana Alit.

Penjelasan tentang kelahiran manusia yang di uraikan dalam lontar ini mirip denganilmuembriology pada manusia atau miripilmutentang kehamilan. Di dalam "Lontas Anggastya Prana" diceritakan bahwa kehidupan bayi selama berada dalam kandungan si Ibu dijaga dan dilindungi oleh Hyang Siwa/ manifestasi Tuhan yang berfungsi sebagai Pamralina. Diceritakan Dewa Siwa memberitahukan kepada Si
Jabang Bayi bahwa, jika ingin lahir ke dunia harus meminta bantuan kepada Sang Catur Sanak. Dikisahkan bahwa Sang Catur Sanak bersedia membantu dan mengikuti Si Jabang Bayi selama hidupnya.

\subsection{Manifestasi Tuhan Dalam Teks Ang- gastya Praṇa}

Tuhan dalam berbagai manifestasinya digambarkan dengan berbagai wujud dan sebutan. Di dalam Veda Tuhan bersifat acintya yang berarti tidak terpikirkan dan sulit digambarkan. Hadirnya simbol sebagai suatu media untuk menggambarkan Tuhan yang tidak terpikirkan, mendadi sesuatu yang berpribadi. Dalam teksAnggastya Praṇa, Tuhan digambarkan dalam tiga manifestasi, yaitu : 1) Tuhan sebagai Sang Hyang Siwatma, 2) Tuhan sebagai Sang Catur Sanak, 3) Tuhan dalam Aksara Suci dalam tubuh manusia.

\subsubsection{Tuhan Sebagai Sang Hyang Siwatma}

Dikisahkan Bagawan Anggastya memiliki dua orang putra yang bernama Sang Subrata dan Sri Satyakreti, yang menanyakan tentang proses awal kelahiran manusia. Diuraikan oleh Bagawan Anggastya bahwa sebutan pertama si calon anak ketika masih mencari-cari tempat lahirnya adalah Sang Hyang Śiwatma. Pencarian ini diakibatkan ketika si calon ayah dan ibu baru beranjak dewasa dan masih mencari-cari pasangan. Dalam teks Anggastya Prana diceritakan bahwa proses awal kelahiran manusia di awali dengan mulainya pembuahan antara spermatozoid (kama petak) dengan telur (kama bhang). PembentukanSang Hyang Antigajati 
dapat dikatakan sebagai prosespembuahan ataufertilisasi (fertilisation).Pada faseini akan dijelaskan bagaimana pembuahan/ fertilisasiitu dapat terjadi hingga nantinya dapat terbentuk benih kehidupan yang disebut dengan Sang Hyang Antigajati.

Penyatuan Kama Bang dan Kama Petakinilah yang kemudian melahirkan Sanghyang Antigajati/embrio. Dimana proses pembentukan Sanghyang Antigajati ini mengalami suatu proses yang cukup panjang. Proses tersebut tetuang dalam teks Anggastya Prana sebagai berikut:

Tityang nunasang satingkahe dados jānma, inggih sapunapike kawite kunā?". Sumawur sang rěși Anggastyapran̄ā, "sapuniki cěning, kawite sane kunā, cěning maraga Sanghyang Siwaatma, duk sang Bapa mwah sang Ibu sami bajang, cěning ngalih tongos, sang Bapa mwah sang Ibu, padha ngělah manah kasěmāran. Smaran sang Bapa, maharan Smarajaya, Smaran sang Ibu maharan Smarā Ratih, cěning maharan Smarasunya. Sami kasusupin madā, sang Bapa mwang Sang Ibu, dadi matěmu kārșa padha harșa, ya matěmu děměn padha děměn. Masalin haranya, sang Bapa Smara Lulut manahnya, sang Ibu Smara wěněng manahnya. Cěning Smara hasa, nga. Nusup ring iBapa mwang ring sang Ibu, kraṇa matěmu padha sukā, cěning dadi Sanghyang Sūnyātma, duk matěmu apasanggama, sira sang Bapa ring sang Ibu. Cěning -/sang- (Teks Lontar Tutur Bhagawan Anggastya Praṇa. 2A).
Terjemahan:

Wahai ayah hamba bertanya tentang asal mula kelahiran m a n u s i a . Dijawablah oleh Sang Resi Anggastya Prana, "beginilah anakku proses awal kelahiran manusia, asal mula anakkuadalah bewujud Sang Hyang Śiwatma, ketika Bapak dan Ibumu beranjak dewasa, dikala itu anakkmmu sedang mencari-cari tempat, ketika BapakdanIbumu,sama-sama merasakan jatuh cinta. Ketika itu asmara Sang Bapak bernama Smara-jaya, asmara Sang Ibu bernama Smara Ratih, ketika itu anakku bernama Smara-sunya. Selanjutnya Sang Bapak dan Sang Ibu dirasuki/terpengaruh asmara, kemudian jadilah bertemu gairah sama gairah, suka sama suka. Lalu berubahlah namanya, Sang Bapak menjadi Smara Lulut pikirannya danSang Ibu Smara wěněng. Saat ini anakku bernama Smara Hasa. Kemudian masuk menyusupi si Bapak dan si Ibu, sehingga menimbulkan suka sama suka. Dan anakku ketika itu engkau bernama Sanghyang Sunyatma, pada saat sang Bapak dan sang Ibu bertemu/bersenggama. Ketika itu anakku bernama Sang.

Kāma molah harane, inusup ring kāman sang Ibu mwah sang Bapa. Nānghing kāmane kasilurang dumun, Ida Bhagawān Dwi, sarěng ring Bāpa Ni Mürtti, sarěng nilurang. Kämane ring sang lanang mūla kāma putih, ring wadon kāmane abhāng, keto kawite wawu ada janima dadwa, luh ring mwani katuturang, mawāșta Sikamoyang Sūkșma, Sikomayang Jāti, pada harěp sang Kakūng 
lāwan sang wadon. Irikā kasilurang kāmane, Ida Bhagawān Dwi sarěng Ibu Patning Mūrtti nilurang kāmane putih ring sang lanang, kämane abāng ring sang wadon. Ditu sang Atmā ngalih tongos, wawu kārșa padha kārșa, sang Atmā ditěngah kārșane magěnah wawu liyat padha liyat, sang Atmā ditěngah liyate magěnah, wawu maśabda padha maśab (Teks Lontar Anggastya Prana. 2B).

Terjemahan:

Kāma Molah, masuk menyusupi kāma/benih sang Ibu dan benih sang Bapak. Namun,kāma/benih tersebut ditukar terlebihdahulu oleh Bhagawān Dwi, dan Bāpa Ni Mūrtti yang ikut menukarnya. Kāma/benih dari lakilaki/bapak awalnya adalah kāma putih, dan benih pada perempuan/Ibu adalah kāma abhāng, begitulah awalnya baru terdapat dua manusia laki-laki dan perempuan, bernama Sikamoyang Sūkṣma dan Sikomayang Jāti, ketika bertemunya sang Kakūng/bapak dengan sangwadon/Ibu.Disanalahditukar kāma/benih tersebut, Ida Bhagawān Dwi dan Ibu Patning Mūrtti lah yang menukarnya. Kāma putih pada sang lanang/si Bapak dan kāma abāng pada sang wadon/ibu. Ketika itulah sang Atmā mencari tempatnya, barulah suka sama suka/sama-sama menginginkan,sangAtmāditengah keinginan tempatnya, baru kemudian pandang memandang, sang Atmā didalam pandangan tempatnya, kemudian saling menyapa.

Kutipan teks Anggastya Prana di atas menegaskan bahwa kelahiran manusia melalui beberapa fase, yaitu : sama-sama beranjak dewasa, saling suka sama suka, sampai terjadinya pembuahan antara Kama Petak dengan Kama Abang sampai pembentukan telur/benih yang bernamaSang Antigajāti. Menurut Lontar ini kelahiran seorang manusia berasal atau bersumber dari Ida Sang Hyang Widhi Wasa dalam manifestasi Beliau sebagai Sang Hyang Śiwatma. Dimana pada kutipan lontar di atas dijelaskan bahwa pada mulanyawujud dari seorang manusia itu adalah Sang Hyang Śiwatma.

\subsubsection{Tuhan Sebagai Sang Catur Sanak}

Catur Sanak oleh masyarakat Hindu di Bali sering disebut dengan istilah Nyama Pat (saudara empat) yang diyakini menemani manusia sejak di dalam kandungan sampai meninggal. Di dalam ajaran Kanda Pat Bhuta dijelaskan bahwa saudara empat itu berjumlah empat, yakni : Yeh ñom (air ketuba), Getih atau Rah (darah), Ari-ari (Uri/Placenta),Banah/ lamas (bungkus lemak pada kulit). Keempat saudara ini menemani manusia dan berganti-ganti nama sesuai dengan perkembangan manusia hingga meninggal. Di dalam teks Anggastya Prana. 6A - 6B juga menguraikan tentang Kanda Pat dan Catur Sanak, yakni sebagai berikut:

Nga..we pati, ngawe pāpa ngawe swargga, swarggan hidup swarggan mati, ngawe buwung ngawe payu, $i k \bar{a}$ apang tangar tingkahe manumadi mānuṣa, apan imānușa dadi umah, umah pāpa muah swargga, ěnto marggan huripe, marggan patine, ènto marggan hala hayune, masusupan dadi bikas mānușane, hatěp pāpa 
swarggane, gěnahnya pati hurip tunggal gěnahnya”. Malih sang putra kālih mātur, "Inggih pakulun päduka sang Rèsi, sapunapi mawinan wentěn Kaṇdha Mpat Bhüta, mwah Kandha Mpat Dewa? Sapunapi malih dados ipun?". Ngandika Ida Sang Rěṣi, "Inggih cěning sapuniki Kandhan ipun: Ari-arine, bāyune, dadi Hantapreta. Rașan ari-arine dadi Pirattha, sarinya dadi Dewa, ada Dewa Puseh-/-mulih (Teks Lontar Anggastya Prana. 6A).

Terjemahan:

„, yang menyebabkan kematian, Itu menyebabkan adanya baik dan buruk, menyebabkan Sorga dan neraka, sorga ketika hidup dan sorga ketika mati, menyebabkan batal dan terjadi, maka dari itu supaya waspada, menjaga prilaku sebagai manusia, karena manușia digambarkan seperti rumah, menjadi rumah sorga dan rumah neraka, itulah jalan kehidupan,jalan kematian, itulah jalan baik dan buruk. Yang merasuk/menyatu menjadi sifat manusia, selalu berdampingan sorga dan neraka itu, begitu juga hidup dan mati menjadi satu tempatnya". Kembali bertanya kedua putra putri Beliau, "Wahai sang Rěsi, bagaimana adanya Kaṇdha Mpat Bhūta dan Kaṇdha Mpat Dewa itu? Dan bagaimana kelanjutannya itu?". Dijawablah oleh Ida Sang Rěși, "baiklah anakku, begini sebabnya itu: bāyu/tenaga darisang Ari-ari/placenta, menjadi Haṇțapreta. Rașa dari ari-ari menjadi Pirattha, sari nya menjadi Dewa, beliau Dewa Pusěh, kembali
Ring papusuh, dadi Anggapati, Swargganya Sanghyang Iśwara, magěnah ring hiděp. Gětihe, dadi Kala, rașanya dadi Atmā, sarinya dadi Dewa di Dalém, mulih ring Ati, dadi Banaspati, swargganya Bhațāra Brāhma, gěnahnya ring Manah. Malih Yeh-ñom, dadi Děngèn, rașanya dadi Parātma, sarīnya dadi Dewa Cungkub, mulih ring Ungśilan, dadi Mrajapati, swargganya Bhatāara Mahādewa, dadi śabdha. Malih Luwune, dadi Bhūta, rașanya dadi Sogatmā, sarinya dadi Dewa Pasaren, mulih ring ring Ampru, dadi Banaspatirā/- swargganya Bhatāra Wiṣnu, dadi Amběk. IkaKaṇdha Mpat Dewaharanya. L-ja Iki śabdanya: IH, AH, HEH, UH. Sabdan Dewa iki, nga: I, ANG, HENG, U. Sadan Atmā,iki, NGHING, NGANG, NGENG,NGUNG,-/- Anging sami dadi kawah, sami swarggan dadinya". Malih (Teks Lontar Anggastya Prana. 6B).

Terjemahan:

pada jantung menjadi Anggapati, Sorganya Sang Hyang Iśwara, bertempat pada hiděp/pikiran. Gětih/ darah, menjadi Kala, rașa nya menjadi Atmā,sarinyamenjadiDewadiDalěm, kembali pada hati, menjadi Banaspati, sorganya Bhațāra Brāhma, bertempat pada Manah/pikiran. Kemudian Yehñom/air ketuba, menjadi Děngěn, rașa nya menjadi Parātma, sari nya menjadi Dewa Cungkub, kembali pada Ungśilan, menjadi Mrajapati, sorganya Bhațāra Mahādewa, menjadi śabdha/suara. Kemudian Luwu/ 
lemak pada kuit, menjadi Bhūṭa, rașa nya menjadi Sogatmā, sari nya menjadi Dewa Pasaren, kembali pada empedu, menjadi Banaspatirāja sorganya Bhațāra Wiṣnu, menjadi Amběk/prilaku. Itulah yang disebut dengan Kaṇdha Mpat Dewa. Ini śabda/ suaranya: IH, AH, HEH, UH. Ini Sabda/suara Dewa: I, ANG, HENG,U. Sabda/suara Atmā ini: NGHING, NGANG, NGENG,NGUNG, namun semua bisa menjadi kawah/neraka/ semua bisa menjadi sorga"

Berdasarkan kutipan teks Anggastya Praṇa di atas bahwa Tuhan bermanifestasi di Bhuana Alit dengan sebutan Catur Sanak dalam Kanda Pat Bhuta dan Kanda Pat Dewa. Catur Sanak atau Nyama Pat (saudara empat). Catur Sanak Dalam Kanda Pat terdiri dari : Yeh Nyom, Getih, AriAri dan Lamas, yang menemani manusia sejak dalam kandungan ampai lahir. Menurut Donder (2007:377)menguraikan bahwaKanda Pat menurut kepercayaan orang Bali tidak hanya berwujud fisik seperti penjelasan di atas namun terdapat juga wujud non fisik/spiritual dari Kandha Pat tersebut yang terdiri dari: Anggapati, Banaspati, Banaspati Raja dan Mrajapati. Dan ungkapan rasasyukur dan terima kasih atas jasa dari keempat saudara/Kandha Pat baik secara fisik dan spiritual diungkapkan dengan melaksanakan beberapa upacara dan ritual-ritual. Sebagai imbalan terhadap empat saudara spiritual bayi itu, maka kepadanya pada waktu ari-ari ditanam diberikan sěgěhan kěpěl. Selanjutnya setiap habis mandi tempat ari-ari disiram dengan air bekas mandi sang bayi. Juga setiap sore dinyalakan lampu, setiap pagi disuguhi sayeban atau ějotan "sejumput makanan lengkap dengan lauk pauknya

\subsubsection{Tuhan Sebagai Akșara Suci Dalam Tubuh Manusia}

Aksara Bali dibedakan atas dua jenis, yaitu aksara biasa dna aksara suci. Aksara biasa terdiri dari dua aksara yaitu aksara wreasta dan swalalita. Disebut aksara biasa, sesungguhnya aksara ini digunakan sehari-hari dalam tulis-menulis. Sedangkan aksara suci juga dibedakan atas dua jenis yaitu aksa Wijaksara ( di Bali di kenal dengan sebutan Bijaksara ) dan Modre. Di dalam teks Anggastya Prana juga diuraikan tentang aksara-aksara suci dalam tubuh manusia sebagai manifestasi Ida Sang Hyang Widhi Wasa dalam wujud aksara suci. Dalam Lontar Anggastya Praṇa diuraikan sebagai berikut:

.....Lwirnya daśākșara ring rāga, iki ya:SANG,ring papusuh gungung Mahāmeru, nga. Wétunya ring Śiwa. Hyang Iśwara, daddharinya Hyang Suprabha, Dewanya Hyang Indra, buronya lèmbu sañjatannya bajra. $B A N G$, ring ati, gunungnya Modra, nga. Tamanya Bagenda, buronya Wilmaṇa, dewanya sanghyang Yāma, sañjatannya Dañdha, dadharinya Dewi Saraswati. TANG, ring ungśilan, gunungnya gunung Lawu, nga. Tamannya Bhāgawit, buronya nāgha, dadharinya dewata Lukih, dewanya Hyang Mahādewa, wètunya pandhita, tras ri lalata, sañjatanya nāghapașa. $A N G$, ring ampru, gunungnya gunung Abang, nga. Tamanya Widhurata, buronya Garudha, dadha-/-rinya Dewi Rantèn Haji (Lontar Anggastya Prana. 15.B) 
Terjemahan:

...Adapun daśākșara dalam diri manusia adalah sebagai berikut: SANG, di jantung (papusuh) tempatnya, gunungnya gunung Mahāmeru. Dewanya hyang Śiwa sebagai Hyang Iśwara, saktinya Hyang Suprabha, Dewanya Hyang Indra, binatangnya lěmbu senjatannya bajra. BANG, di hati tempatnya, gunungnya gunung Modra. TamanyaBagenda, binatangnyanya Wilmaṇa, dewanya sanghyang Yāma, senjatannya Dañdha, saktinya Dewi Saraswati. TANG, pada ginjal (ungśilan) tempatnya, gunungnya gunung Lawu. Tamannya Bhāgawit, binatangnya nāgha, Saktinya dewata Lukih, dewanya Hyang Mahādewa, keluarnya pandhita, yoganya ditengahtengah kening, senjatanya nāghapașa. ANG, di nyali (ampru) tempatnya, gunungnya gunung Abang. Tamanya Widhurata, binatangnya Garudha, saktinya Dewi Rantěn Haji,

Dewanya Wiṣnu, trusing tinghal, wětunya prabhu. ING, ring madhya, gěnahnya ring pangantungan hatine, gunungnya Argghamanik,nga. Tamanya Tlagakanța, buronya gajah, dewanya Hyang Śiwā, dadharinya Śrī wirocana. NANG, ring paparu, ngnungnya gunung Mateyā, tamanya Sakșari, nga. Dewanya Hyang Maheśora, dadharinya Sri Mahādewi, trus ring hirung, wètunya Brāhmaṇa. $M A N G$, ring usus gung, gěnahnya, dewanya Hyang Rudra, dadharinya padukaśwari, trus ring lidah, wětunya Parama Rěși. SING, ring limpha gěnahnya, dewanya Hyang Śangkara, dadharinya Śr̄̄ Mahādewi trus ring hirung, WANG, ring hiněban gěnahnya, dewanya Hyang Śambhu, gunungnya gunung Ambala, tamannya Wari, nga. Buronya Warak, dadharinya Gagar Ma-/-yang, trus ring rambut, wětunya Bhujangga.

......YANG, ring Madhya gěnahnya, ring pangantunganing papusuh gěnahnya, gunung Aṇdhabhawana, nga. Tamannya Padadaran, buronya wenatya, nga. Linggih Ida Bhatāra Siwa,panungalannya dadhari kabeh, ring pangantungan papusuhane, pangantungan hati gěnahnya Sanghyang Hurip......(Teks Lontar Anggastya Prana. 16A-16B).

Terjemahan:

Dewanya Wiṣnu, yoganya di mata, keluanya prabhu. ING, di tengahtengah, tempatnya di pangantungan hati, gunungnya Argghamanik. Tamanya Tlagakaṇța, binatangnya gajah, dewanya Hyang Śiwā, saktinya Śrī wirocana. NANG, di paru-paru tempatnya, gunungnya gunung Mateyā, tamanya Sakșari. Dewanya Hyang Maheśora, saktinya Sri Mahādewi, yoganya di hidung, keluarnya Brāhmaṇa. MANG, di usus besar tempatnya, dewanya Hyang Rudra, saktinya padukaśwari, yoganya dilidah, keluarnya Parama Rěși. SING, di limpha tempatnya, dewanya Hyang Śangkara, saktinya Śrī Mahādewi, yoganya di hidung, WANG, di hiněban tempatnya, dewanya Hyang Śambhu, gunungnya gunung Ambala, tamannya Wari. binatangnya Warak, 
saktinya Gagar Mayang, yoganya di rambut, keluarnya Bhujangga. ... YANG, di tengah-tengah tempatnya, di pangantungan papusuh tempatnya, gunungnya Andhabhawana namanya. Tamannya Padadaran, binatangnya wenatya namanya. Tempat/stana dari Ida Bhațāra Śiwa, panungalan dari semua sakti, di pangantungan (jantung) papusuh, pangantungan hati tempatnya Sang Hyang Hurip...

Terlihat jelas tentang penggambaran Tuhan dalam tubuh manusia dalam wujud aksara suci. Aksara suci terdapat di jantung, hati, ginjal, nyali, tumpukin hati, paruparu, usus, ineban dan gantungin hati. Dari organ tubuh manusia disimbolkan dengan aksara suci dan merupakan perwujudan dari aksara suci Tuhan. Aksara SANG merupakan simbol dewa Iswara, aksara BANG merupakan sibol dewa Brahma, aksara TANG merupakan simbol dewa Mahadewa, aksara ANG merupakan simbol Dewa Wisnu, Aksara NANG merupakan simbol dewa Mahesora, aksara MANG merupakan simbol dewa Rudra, SING simbol dewa Sambhu, WANG simbol dewa Sankara, dan ING dan YANG merupakan simbol dewa Siwa. Dari konsep saudara empat atau sering disebut Catur Sanak kemudian berkembang menjadi Dewata Nawa Sangga (dewata penjuru mata angin). dalam teks Anggasta Prana mengisyaratkan sebuah proses menuju Tuhan melalui kontemplasi aksara suci dalam tubuh yang berujung pada penyatuan Bhuana Agung dengan Bhuana Alit. Bhuana Agung disimbolkan dengan penggambaran Dewata Nawa Sangga, dan simbol Bhuana Alit adalah tubuh manusia dengan Dasa
Aksara. Perputaran yang teratur di Bhuana Agung dengan Bhuana Alit bermuara pada penyatuan menuju harmonisasi atau keseimbangan alam Mikro kosmos dan makro kosmos.

\section{SIMPULAN}

Teks Anggastya Prana menekankan bahwa tubuh manusia (sarira) merupakan perwujudan kecil (Bhuana Alit) dari penggambaran alam semesta (Bhuana Agung). Dinyatakanbahwa proses kelahiran manusia melewati tiga fase, perkembangan sebagai manefestasi Tuhan dalam diri. Fase pertama, diawali oleh suka sama suka, dan pada usia remaja hinga terjadi hubungan/ sanggama sampai terjadi pembuahan antara spermatozoid (kama petak) dengan ovum (kama bhang) menjadi Sang Hyang Antigajati berupa benih kehidupan. Ketika anak sedang mencari - cari kelahirannya disebut dengan Sang Hyang Siwatma. Fase kedua, ketika manusia lahir kedunia, ia ditemani oleh saudara empat yang disebut Catur Sanak yang berupa Yeh Nyom (air ketuban), ari-ari, lamas, dan darah. Sang Catur Sanak menemani manusia dari kelahiran dengan sebutan Sang Anggapati, Sang Prajapati, Sang Bhanaspati, dan Sang Bhanaspatiraja, sampai manusia mati dan berganti sebutan sesuai perkembangan manusia. Fase ketiga, adalah penggambaran Tuhan dalam tubuh manusia berupa simbol aksara suci. Penyatuan konsep Catur Sanak berupa aksara suci yang disebut Dasaksara, bersinergi dengan konsep Dewata Nawa Sngga (dewata sembilan penjuru mata angin) menciptakan keharmonisan Bhuana Agung (alam semesta) dengan Bhuana Alit (tubuh manusia). 


\section{DAFTAR PUSTAKA}

Pusdok Kebudayaan Bali, 1998. Lontar Tutur Bagawan Anggastya Prana.

Abidin, Zainal. 2006. Filsafat Manusia: Memahami Manusia Melalui Filsafat. Bandung: PT. Remaja Rosdakarya.

Anandakusuma, Sri Reshi. 1985. Aum Upacara Manusa Yadnya. Denpasar : CV. Kayumas Agung.

Donder, I Ketut. 2007. Kosmologi Hindu. Surabaya: Paramita.

Pendit, Nyoman S. 2007. Filsafat Hindu Dharma Șaụ Darśana. Denpasar: Pustaka Bali Post.

Peursen, Van C. A. 1979. Tubuh Jiwa Roh. Terjemahan oleh K. Bertens. 1983. Jakarta: PT. BPK Gunung Mulia.

Sanadji, Kasmiran Wuryo. 1985. Filsafat Manusia. Jakarta: Erlangga.

Subagiasta, I Ketut. 2008. Pengantar Acara Agama Hindu. Surabaya: Paramita.

Tim Penyusun, 2002. Kamus Istilah Agama Hindu. Denpasar : Pemerintah Propinsi Bali. 